\title{
Composition of board of directors and performance: evaluating the mediating effect of innovation
}

\section{Tarika Singh Sikarwar}

Prestige Institute of Management, Opposite DD Nagar, Airport Road, Gwalior, 474020, India Email: singh.tarika@gmail.com Email: tarika.singh@prestigegwl.org

\begin{abstract}
Board of directors have corporate credit risk on the top of their minds. Risk management is now a governance issue too. The study observes the affiliation amid the composition of the 'board of directors' and the firm's 'financial performance' through the mediating effect of 'innovation activities'. This empirical work is centred on manufacturing corporations recorded in the Stock Exchange of India with the data taken from the NSE website and the company's annual reports from the year 2008 to 2018. The results of the linear regression showed that there is an affiliation that exists between the 'composition of the board of directors' and the 'financial performance' of manufacturing firms. The mediating effect of 'innovation activities' has significantly shown evidence of mediation. The study has implications for the assessment of credit risk of an organisation through the composition of the board of directors as well as innovation practices.
\end{abstract}

Keywords: board of directors; financial performance; microeconomics; stock exchange; manufacturing firms; innovation index; credit risk.

Reference to this paper should be made as follows: Sikarwar, T.S. (2021) 'Composition of board of directors and performance: evaluating the mediating effect of innovation', Int. J. Critical Accounting, Vol. 12, No. 1, pp.1-16.

Biographical notes: Tarika Singh Sikarwar is a resourceful and innovative professional with a $15+$ year academic career producing powerful learning opportunities for advanced level post-secondary courses, international educational facilities, and corporate training. She is recognised for teaching excellence based on technical, research, and design fundamentals, pioneering technology in the classroom and e-learning, strong follow-through, administrative and time management capabilities, highly articulate, demonstrating refined interpersonal skills across all levels and backgrounds, without fail, confident, positive and professional. She is energised for new challenges and trusted to orientate new faculty addressing teaching methodologies and student expectations in a college environment.

\section{Introduction and theoretical background}

In this research paper, authors have tried to explore the impact of the 'board of directors' on the profitability of manufacturing firms by taking innovation activities as a mediating variable. Further, the implications of the results are discussed for credit risk in such firms. Innovation has been acknowledged as one of the most crucial elements for development 
and has a competitive position in the market. In manufacturing firms, there is a separation of management and control, which gives a space for discretion in decision-making as well as scope to pursue self-motives. Also, future outcomes of research and development projects are relatively uncertain and cannot be predicted accurately. This may lead managers to focus on short-term financial performance, keeping aside sustainable innovation strategies that are bound by longer time horizon and high risk. Managers hence may focus on capitalising on short-term compensation (Aghion et al., 2013; Manso, 2011). Board of directors rather than getting involved in day to day practices should take care of the risk management policies, especially credit risk, through risk managers and senior level executives (Lipton et al., 2018). Even the responsibilities and roles of board of directors needs to reviewed periodically to ensure the inclusive efforts. A good board of director considers use credit risk tools to assess the risk in any of the business deals.

The previous researches in the area have focused on role of corporate governance indicators on innovations (Aghion et al., 2013; Czarnitzki and Kraft, 2009; Ughetto, 2010), supervision physiognomies and skills on innovations (Barker and Mueller, 2002; Galasso and Simcoe, 2011; Talke et al., 2010), and influence of non-executive outside directors on innovation (Balsmeier et al., 2014).

Assorted human capital on sheets impacts the vital course of the firm by giving psychological clash which may bring about advancement. Assorted sheets may flag adherence to social laws and qualities, just as the capacity to comprehend various partners and markets in which the firm does the business. Innovation as approaches provides novel openings for the firm to create products or services. The composition of innovation indicators shows the quality of the firm to the public, influence the firm's reputation. Corporate innovation strategies are the strategies that give novel tactical opportunities to the firm to generate new services or product lines. Innovation is the basic success key strategy of the firm through which it can gain a competitive advantage, can expand market share and grow firm performance (Pisano, 2015). As innovation is vivacious to a firm, directors on the board always feel challenged with respect to assigning possessions and generating more ideas for enhancing the modernisation of a firm. Board diversity act as a planned human and social capital resource so as to catalyse the efforts, thus up surging innovation. Executive directors are mainly responsible for the controlling of procedures.

Innovative business models of companies should consider risk as well as it is unavoidable part of business. Conventionally, economists have explained managerial behaviour using agency theory. An organisation might not invest in innovative long-term oriented projects as they do not improve the long-term valuation of a manager. On the contrary, not investing might improve the short-term maximisation of profits (Hirshleifer, 1993). The erratic results of innovative schemes lead risk-averse managers to lessen outlay on any inventive project (Manso, 2011). There is also contrary research wherein it is visible that if managers have enticements for the advanced rate of innovative activities, the profitability of the firm will increase (Czarnitzki and Kraft, 2009). So, it can be concluded that the extent and type of innovative activities undertaken by a firm also depend on the inclinations and characteristics of the CEO (Barker and Mueller, 2002; Green, 1995).

Despite the fact that as of late, numerous specialists have been concentrating on this field of study, an increasingly predictable clarification despite everything should be found for these relations. Additionally, since the exact proof is not broad, most earlier 
examinations have investigated the effect on advancement of the level of ownership fixation (Cho, 1998; Ortega-Argilés et al., 2005; Brunninge et al., 2007; Czarnitzki and Kraft, 2009; Shapiro et al., 2015 as cited in Asensio-López et al., 2019). Hence, the present work has its importance as the area to be explored, i.e., the mediating effect of innovative practices in firm between composition of board of directors and firm's performance is yet to be explored in India. The paper starts with introduction to the topic, then scanning existing work, followed by rationale, objectives, exploration procedure and results and discussion. Lastly, conclusions, implications and references are presented.

\section{Scanning existing work}

Suggesting the affiliation among board composition and performance via two mediators: firm reputation and innovation for a section of Fortune 500 firms, Miller and Trian (2009) established an affirmative affiliation between 'board racial diversity' and both 'firm reputation' and 'innovation' as well as among board gender diversity and innovation.

Carpenter and Westphal (2001) worked on external network ties helps to control a board ability to lead decision-making process and found that the modest number of director arrangements to other boards does not affect board governing of strategy or choice which can give the director a strategic knowledge and viewpoint do predict such involvement.

Tacheva and Huse (2006) investigated the affiliation between a women board member and board task performance. The result suggested the figure of women directors has a straight adverse bearing on the performance of two of the board task, namely, financial control and service task. There is marginal support for a positive controlling effect of board trust on the link between women directors and qualitative control performance. Ayuso and Argandona (2007) have proposed that diverse stakeholders in the board promote CSR activities within the organisation. Balta et al. (2006) further explored that the process of strategic decision-making act as a mediator among board members' demographic characteristics and corporate innovation relating to the product, process and organisation.

Duzta et al. (2008) inspected the controlling effects of transparency and information technology on board structure and company performance. The author also studied the affiliations on the measurements of board characteristics, transparency, information technology and company performance. Shadab (2008) also explored the affiliation between innovation and corporate governance and found that governance structures, lay emphasis on strategic internal control and facilitate innovation. Chieh (2013) studied the consequence of capital structure on corporate performance and found a positive interactive effect of corporate 'innovation activities' on the affiliation between capital structure and corporate performance. Corporate 'innovation activities' noticeably accelerate the effect of capital structure. Robeson and O'Connor's (2013) study for Fortune 1,000 firms suggested that the affiliation between the 'board of director's' behaviour and the firm's overall innovativeness is facilitated by innovation decision-making boards.

Blair and Stout (2001) studied that directors may act trustworthy even when they are not having obvious encouragement to do so and also came up with some of the situations that are likely to encourage responsible director behaviour. Ford-Eickhoff et al. (2011) 
investigated the affiliation between larger knowledge amongst hospital board members, 'board involvement' in the stages of strategic decision-making, and the hospital's strategic focus and found that there is an affiliation between both the nature and involvement of the board and the hospital's 'strategic orientation'.

Beekman et al. (2012) studied the affiliation between innovation an entrepreneurial orientation where they applied an entrenched build, pioneering direction, and investigate the enterprising arrangement among three basic entertainers the official executives, 'top managerial staff', and key staff individuals to build-up a model and recommendations.

He and Mahoney (2006) recognised firm-level focused action, one of the key units of examination in aggressive elements investigate, as the crucial intervention between corporate governance and firm-level 'financial performance'. Babic et al. (2011) have debated on board role performance and proposed that role should include structural and process variables as well.

Staubo (2014) is also of opinion that any type of pieces of evidence does not prove that more boards' independence completely advances firm value. Mention (2012) in his work on a firm's resources and activities and their influence on its intangible assets, innovation, and performance, explored that an intellectual capital oriented framework affects the innovation and has an effect on performance.

Gil (2005) examined difficulties in linking the performance of governing boards to organisational effectiveness. The paper raised the concern that CEO and staff performance, perhaps the major intervening variable between board performance and organisational effectiveness. Ukaegbu et al. (2014) observed a conflicting affiliation between capital structure and the firm's performance. Also, they found a positive relationship between a firm's performance leverage, number of board meetings and board composition. Aggarwal (2013) examined the affiliation between cognitive style diversity and team performance and identified strategic focus, strategic consensus, transitive memory, and learning as explanting variables of affiliation

Cheung et al. (2011) studied the affiliation between venture capital and the new venture performance of new venture enterprise. Through the empirical validation on the 149 samples, it concluded that value protection and value creation governance activities have played a catalytic role in the performance of the new enterprise, but their contents and path differs.

Ghazi and Rim (2014) showed the importance of the domination of inside directors in the 'board of director's'. It also shows the importance of research and development in the performance of the company. They also stated the affiliation between the inside directors, 'board of directors' and the research and development of the company as more the no. of inside directors (who promote research and development) in the board more the performance of the firm. Haldar (2017) studied that there is not much influence on the performance of the firm due to independent directors on the board of the company.

Rathnayake and Sun (2017) stated that there is an influence of corporate governance on firm's performance. The study also showed a positive influence of board size and firm's age on return on asset (ROA).

Arora (2012) addressed the influence of 'corporate governance' on 'firm performance'. Also, that the inside directors' prominently affect the firm's performance as compared to the outside directors. However, the 'duality of the CEO' role has an adverse outcome on performance. Gugong et al. (2014) studied the effect of managerial shareholding and institutional shareholding on the firm's performance. This study stated the positive effect of both the variables on the firm's performance. 
Haldar and Rao (2011) studied the connection between ownership structure and firm performance. The results showed that promoters' holding has an important impact on the act as compared to no-promoters. Koufopoulos and Gkliatis (2018) mentioned that organisational size and age have a considerable outcome on board size. But the CEO nature (duality, dependence and independence) is no significant effect. Kang and Zardkoohi (2005) stated that there is no consequence on CEO duality on the firm's performance, rather it majorly depends on the conditions in which duality is adopted.

The following are the hypotheses set after review in the concerned area:

Ha1 'Percentage of insider directors on the board' has a noteworthy and encouraging effect on the innovation level and together affects the performance of the firm positively.

Ha2 'Duality' has a noteworthy and encouraging effect on the innovation level and together affects the performance of the firm positively.

Ha3 'Board size' influences the innovation level and together affects the performance of the firm positively.

Ha4 'Innovation index' affects the performance of the firm positively.

Ha5 'Percentage of insider directors on the board' has positive association with innovation index.

Ha6 'Duality' has positive association with innovation index.

Ha7 'Leadership structure of the board' has positive association with innovation index.

Ha8 'Percentage of insider directors on the board', 'duality' and 'leadership structure of the board' as independent variables with innovation index as mediating variable affects performance of firm.

\section{The rationale of the study}

Previous researchers found a constructive affiliation between board gender diversity and innovation. They identified that the innovation functions as facilitating variables which transmit the result of variety to firm performance. But there is a need for innovation in this dynamic environment and cutthroat competition. It is important to understand the degree to which top management advice that is helpful for the growth of the organisation as all crucial decision made by top management regarding innovation and other's matters of the organisation and innovation is one of the significant activities for the organisation growth and it is also important for the survival and stability.

\section{Objectives of the study}

- To discover affiliation between 'board of director's', board size, CEO duality, innovation index, firm size of sector listed firms and ROA.

- To discover affiliation between 'board of director's', board size, CEO duality, innovation index, firm size of sector listed firms and return on equity (ROE). 
- To discover affiliation between 'board of director's', board size, CEO duality, innovation index, firm size, of sector listed firms and innovation index.

- To discover the mediating effect of innovation index by taking ROA and ROE as dependent and considering 'board of director's', board size, CEO duality, innovation index, firm size, of sector listed firms as an independent.

\section{Exploration procedure}

The study was empirical and secondary data was used to complete it. The population taken was of all those companies listed with any of the 'stock exchange' in India. The timeframe considered is from FY 2008-2018. The sample size was 30 manufacturing firms which are continuously listed in NSE. Secondary sources were used for collecting the data website of NSE as well as individual company websites.

Taking manufacturing firms for sample has its own relevance. Environment changes signify changes in taste and preferences of customers. Technology leap makes existing products, manufacturing practices as well as business models obsolete. Hence, firms have to innovate at an ever increasing rate.

These advancements in technology pose significant challenges to manufacturing firm to innovate. Hence, studying manufacturing firms was a well thought decision.

Understanding the variety of the variables of the study, the data for the same was collected through various sources, the majority being secondary sources like the published financial statements, financial reports of the companies.

\section{Model and variables measurements}

The association between the board characteristics, the innovation activities, and performance of the firm, can be depicted through the following model (Figure 1).

Figure 1 Theoretical model (see online version for colours)

Board characteristics $\rightarrow$ Innovation $\rightarrow$ Firm performance

In this model, some indicators have been taken to represent board characteristics, innovation activities and firm performance. These indicators are explained in the below-given section. The summarised variables measurements of this study taken from Chouaibi et al. (2017).

\subsection{Variables of the study}

- Firm performance as measured by 'financial performance' was determined by using ROA and ROE ratios.

$$
\begin{aligned}
& \text { ROA }=\text { Net total income } / \text { Average total asset } \\
& \text { ROE }=\text { Net income } / \text { Average stock holder's equity }
\end{aligned}
$$


- Excess return on ROE and ROA was calculated using the formula:

Return $=100 *$ today return - previous return / previous return

- Board characteristics was measured by below-given indicator:

a 'Percentage of insider directors on the board' (PerlnsD): Number of directors on the board, directly employed with or have professional ties with the firm, as a percentage of the total board size.

b c(duality): Dummy variable with the firm having the same individual acting as the CEO and chairperson of the board being scored one, otherwise a zero.

c 'Board size' (Bdsize): Number of directors serving on the board.

d 'Firm size' (LOGTA): The natural log of the total assets.

e 'Sector' (SECT): A binary variable that takes value 1 if the firm belongs to a high-tech sector and 0 if the firm belongs to a traditional sector.

f 'Listed firms' (LIST): A binary variable that takes value 1 if the firm is listed on the national 'stock exchange' and 0 otherwise.

- Mediating variable: 'Innovation index' (INVTIND): The innovation index refers to all innovations in the firm. The entire 'innovation activities' which are maintained and categorised agreeing to a 'scoring' system for the industrial companies. 'Innovation index': denotes to all the novelties in the firm (Chouaibi et al., 2017).

\subsection{Tools used for data analysis}

- Linear regression analysis and Sobel test were applied to examine the hypothesis of the direct and indirect effects of the 'board's characteristics' on the 'financial performance' through 'innovation activities', respectively.

\section{Results and discussion}

PASW 18 was used to explore the collected data. Multiple linear regressions were used for exploring the causal association between the predictors and the dependent variable. The following section discusses them in detail.

\subsection{Normality test}

For understanding the normal distribution of data on the various variables, the Jarque-Bera test was applied. From Table 1, results for variables ROA, LROA, ROE, LROE, RTRN, LRTRN, and LTA states that test value is more than the $0.5 \%$ signifying the normal distribution of data while the other variables PISD, LPISD, DLTY, LDLTY, BSIZE, LBSIZE, LTA, SCT, LSCT, LIST, and LLIST have no any result due to insufficient no. of observations. 
Table 1 Descriptive statistics

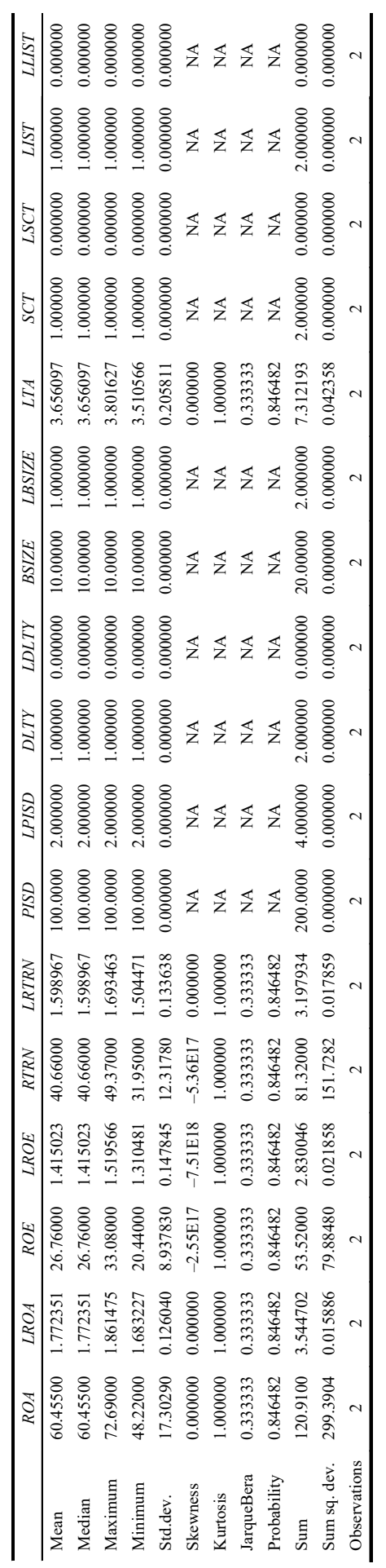




\subsection{Causation analysis}

In Table 2a, the R square of PISD is .042 representing the amount of alteration for a dependent variable ROA that is $4.2 \%$ clarified by the independent variable. The $\mathrm{F}$ value for PISD in Table 2a measures the model fit and its value is 6.017 , significant at .003 considering the model is fit. The value of $\beta$ is .126 with a T-value of equals 2.098 at .037 level of significance showing significant affiliation between PISD and ROA.

Table 2a Summary of causation analysis

\begin{tabular}{lcccccc}
\hline $\begin{array}{l}\text { Dependent } \\
\text { variable }\end{array}$ & $\begin{array}{c}\text { Independent } \\
\text { variable }\end{array}$ & $R 2$ & F-value@Sig & $\beta$ & T-value & Significance \\
\hline ROA & PISD & 0.042 & $6.017 @ 0.003$ & 0.126 & 2.098 & 0.037 \\
& DLTY & 0.031 & $4.405 @ 0.013$ & & & \\
& BSIZE & 0.027 & $3.825 @ 0.023$ & 0.016 & 0.261 & 0.795 \\
& $\begin{array}{c}\text { Innovation } \\
\text { index }\end{array}$ & 0.056 & $16.490 @ 0.000$ & 0.059 & 0.988 & 0.324 \\
\hline
\end{tabular}

Table 2b Summary of causation analysis continued

\begin{tabular}{lcccccc}
\hline $\begin{array}{l}\text { Dependent } \\
\text { variable }\end{array}$ & $\begin{array}{c}\text { Independent } \\
\text { variable }\end{array}$ & $R 2$ & F-value@Sig & $\beta$ & T-value & Significance \\
\hline ROE & PISD & 0.07 & $10.310 @ 0.000$ & -0.268 & -4.525 & 0 \\
& $\begin{array}{c}\text { Innovation } \\
\text { index }\end{array}$ & 0.056 & $16.490 @ 0.000$ & -0.237 & -4.061 & 0 \\
\hline
\end{tabular}

Table 2c Causation summary continued

\begin{tabular}{lcccccc}
\hline $\begin{array}{l}\text { Dependent } \\
\text { variable }\end{array}$ & $\begin{array}{c}\text { Independent } \\
\text { variable }\end{array}$ & $R 2$ & F-value@Sig & $\beta$ & T-value & Significance \\
\hline Innovation & PISD & -0.001 & $0.915 @ 0.455$ & 0.115 & 1.818 & 0.07 \\
index & DLTY & & & -0.02 & -0.318 & 0.751 \\
& DLTY & & & 0.048 & 0.775 & 0.439 \\
& LTA & & & -0.033 & -0.516 & 0.606 \\
\hline
\end{tabular}

Data for other independent variables were not found suitable for regression analysis.

Ha1, 'percentage of insider directors on the board' has a noteworthy and encouraging effect on the innovation level and together affects the performance of the firm positively, is accepted.

In Table 2a, the R square of DLTY is .031 representing the amount of alteration for a dependent variable ROA that is $3.1 \%$ clarified by the independent variable. The $F$ value for DLTY in Table 2a measures the model fit and its value is 4.405 , significant at .013 considering the model is fit.

Data for other independent variables were not found suitable for regression analysis.

$\mathrm{Ha} 2$, 'duality' has a noteworthy and encouraging effect on the innovation level and together affects the performance of the firm positively is accepted.

In Table $2 \mathrm{a}$, the $\mathrm{R}$ square of BSIZE is .027 representing the amount of alteration for a dependent variable ROA that is $2.7 \%$ clarified by the independent variable. The $\mathrm{F}$ value for BSIZE in Table 2a measures the model fit and its value is 3.825 , significant at .023 
considering the model is fit. The value of $\beta$ is .016 with a t-value of equals .261 at .795 level of significance showing significant affiliation between BSIZE and ROA.

Data for other independent variables were not found suitable for regression analysis.

Ha3, 'board size' influences the innovation level and together affects the performance of the firm positively is accepted.

In Table 2a, the $\mathrm{R}$ square of Innovation Index is .056 representing the amount of alteration for a dependent variable ROA that is $5.6 \%$ clarified by the independent variable. The $\mathrm{F}$ value for innovation index in Table $2 \mathrm{a}$ measures the model fit and its value is 16.490 is significant at .000 considering the model is fit. The value of $\beta$ is .059 with $\mathrm{T}$ value of equals .988 at .324 level of significance showing significant affiliation between innovation index and ROA.

Data for other independent variables were not found suitable for regression analysis.

Ha4, 'innovation index' affects the performance of the firm positively, is accepted.

In Table 2b, the R square of PISD is .007 representing the amount of alteration for a dependent variable ROE that is $0.7 \%$ clarified by the independent variable. The $\mathrm{F}$ value for PISD in Table $2 \mathrm{~b}$ measures the model fit and its value is 10.310 is significant at .000 considering the model is fit. The value of $\beta$ is .268 with $T$ value of equals -4.525 at .000 level of significance showing significant affiliation between PISD and ROE.

Data for other independent variables were not found suitable for regression analysis. Hence, Hal is accepted.

In Table $2 b$, the $\mathrm{R}$ square of innovation index is .056 representing the amount of alteration for a dependent variable $\mathrm{ROE}$ that is $5.6 \%$ clarified by the independent variable. The $\mathrm{F}$ value for innovation index in Table $2 \mathrm{~b}$ measures and the model fit its value is 16.490 is significant at .00 considering the model is fit. The value of $\beta$ is .237 with a $\mathrm{T}$ value of equals -4.061 at .000 level of significance showing significant affiliation between innovation index and ROE.

Data for other independent variables were not found suitable for regression analysis. Hence, Ha4 is accepted again.

In Table $2 \mathrm{c}$, adjusted $\mathrm{R}$ square for BSIZE is -.001 . This means that the $-0.01 \%$ variation in innovation index is clarified by the independent variables used in the research. This means the independent variables are having an affiliation with the dependent variable. The F value for BSIZE in Table $2 \mathrm{c}$ measures the model fit and the model fit its value is .915 is significant at .455 considering the model is fit. The value of $\beta$ is .115 with a $T$ value of equals 1.818 at .007 level of significance showing significant affiliation between BSIZE and innovation index.

Data for other independent variables were not found suitable for regression analysis. Hence, Ha3 is accepted again.

In Table 2c, adjusted $\mathrm{R}$ square for PISD is -.001 . This means that the $-0.01 \%$ variation in innovation index is clarified by the independent variables used in the research. This means the independent variables are having an affiliation with the dependent variable. The F value for PISD in Table $2 \mathrm{c}$ measures the model fit and the model fit its value is. 915 is significant at .455 considering the model is fit. The value of $\beta$ is -.02 with $\mathrm{T}$ value of equals -.318 at .751 level of significance showing significant affiliation between the PISD and innovation index. Hence, Ha5, 'percentage of insider directors on the board' has positive association with Innovation Index is accepted.

Data for other independent variables were not found suitable for regression analysis. 
In Table 2c, adjusted $\mathrm{R}$ square for DLTY is -.001 . This means that the $-0.01 \%$ variation in innovation index is clarified by the independent variables used in the research. This means the independent variables are having an affiliation with the dependent variable. The F value for DLTY in Table $2 \mathrm{c}$ measures the model fit and the model fit its value is .915 is significant at .455 considering the model is fit. The value of $\beta$ is .048 with $\mathrm{T}$ value of equals .775 at .439 level of significance showing significant affiliation between the DLTY and innovation index.

Hence, Ha6, 'duality' has positive association with innovation index, is accepted.

Data for other independent variables were not found suitable for regression analysis.

In Table 2c, adjusted $\mathrm{R}$ square for LTA is -.001 . This means that the $-0.01 \%$ variation in innovation index is clarified by the independent variables used in the research. This means the independent variables are having an affiliation with the dependent variable. The F value for LTA in Table $2 \mathrm{c}$ measures the model fit and the model fit its value is .915 is significant at .455 considering the model is fit. The value of $\beta$ is -.033 with $\mathrm{T}$ value of equals -.516 at .606 level of the significance level of significance showing significant affiliation between the LTA and innovation index. Hence Ha7, 'leadership structure of the board' has positive association with innovation index, is accepted.

Data for other independent variables were not found suitable for regression analysis.

\subsection{Mediating effect}

\subsubsection{Where ROA is a dependent variable, board size, PISD, DLTY, and LTA is an independent variable and the mediator variable is the innovation index}

In Table 3a, two-tailed probability is considered. The statistic that the 'observed $p$-value' decrease above the recognised alpha level of .05 specifies that the relationship amongst the IV and the DV is condensed meaningfully by the addition of the mediator in the model; in other words, there is a sign of mediation. The Sobel test statistic is -0.00163382 with one-tailed probability 0.49934820 and two-tailed probability 0.99869640 .

In Table 3b, two-tailed probability is considered. The statistic that the 'observed $p$-value' falls above the recognised alpha level of .05 designates that the relationship between the IV and the DV is condensed meaningfully by the addition of the mediator in the model; in other words, there is a sign of mediation. The Sobel test statistic is -0.00163378 with one-tailed probability 0.49934822 and two-tailed probability 0.99869643 .

Table 3a Mediation results

\begin{tabular}{|c|c|c|}
\hline A: & -0.048 & $\begin{array}{l}\text { "The regression coefficient for the affiliation between the independent } \\
\text { variable and the mediator". }\end{array}$ \\
\hline B: & 0.059 & $\begin{array}{l}\text { "The regression coefficient for the affiliation between the mediator and the } \\
\text { dependent variable". }\end{array}$ \\
\hline SEA: & 0.187 & $\begin{array}{l}\text { "The standard error of the affiliation between the independent variable and } \\
\text { the mediator". }\end{array}$ \\
\hline SEB: & 36.111 & $\begin{array}{l}\text { "The standard error of the affiliation between the mediator variable and the } \\
\text { dependent variable". }\end{array}$ \\
\hline
\end{tabular}


Table 3b Mediation results continued

\begin{tabular}{lll}
\hline A: & -0.048 & $\begin{array}{l}\text { "The regression coefficient for the affiliation between the independent } \\
\text { variable and the mediator". }\end{array}$ \\
B: $\quad 0.059$ & $\begin{array}{l}\text { "The regression coefficient for the affiliation between the mediator and the } \\
\text { dependent variable". }\end{array}$ \\
SEA: $\quad 0.187$ & $\begin{array}{l}\text { "The standard error of the affiliation between the independent variable and the } \\
\text { mediator". }\end{array}$ \\
SEB: $\quad 36.111$ & $\begin{array}{l}\text { "The standard error of the affiliation between the mediator variable and the } \\
\text { dependent variable". }\end{array}$
\end{tabular}

Table 3c Mediation results continued

\begin{tabular}{lll}
\hline A: & 0115 & $\begin{array}{l}\text { "The regression coefficient for the affiliation between the independent } \\
\text { variable and the mediator". }\end{array}$ \\
B: & -0.237 & $\begin{array}{l}\text { "The regression coefficient for the affiliation between the mediator and the } \\
\text { dependent variable". }\end{array}$ \\
SEA: $\quad 0.187$ & $\begin{array}{l}\text { "The standard error of the affiliation between the independent variable and } \\
\text { the mediator". }\end{array}$ \\
"ThE & 36.111 & $\begin{array}{l}\text { "The standard error of the affiliation between the mediator variable and the } \\
\text { dependent variable". }\end{array}$
\end{tabular}

\subsubsection{Where ROE is a dependent variable, board size, PISD, DLTY, and LTA is} the independent variable and the mediator variable is the innovation index

In Table 3c, two-tailed probability is considered. The statistic that the 'observed $p$-value' falls above the recognised alpha level of .05 indicates that the relationship between the IV and the DV is condensed meaningfully by the addition of the mediator in the model; in other words, there is a sign of mediation. The Sobel test statistic is -0.00656310 with one-tailed probability 0.49738172 and two-tailed probability: 0.99476344

Hence, Ha8, 'percentage of insider directors on the board', 'duality' and 'leadership structure of the board' as independent variables with innovation index as mediating variable affects performance of firm, is accepted.

\section{Conclusions}

This study has surveyed the intermediating role of 'innovation' on the connection amongst the board composition and firm 'financial performance'. Today, innovation is at the heart of highly successful firms. Innovation is, therefore, able to offer new solutions that meet specific needs and whether new products, new processes or new services. The innovative behaviour is the intended construction, the institution and the use of novel thoughts in an operational role, group of people or business. The motive is to surge the performance of individuals, group or organisations. The results of this empirical study show that the organisational environment and especially the governance structure of the firm have a central stimulus on the innovation decision-making process. Board composition facilitates the affiliation between ownership structure and innovative behaviour. It proposes that the success of a firm in aligning itself to the market as well as 
coming up with the new product or service depends upon the internal organisation of the firm. In the year 2006, Boone et al. also came up with the conclusion that a large 'board of directors' primes to better 'financial performance'.

From the results of the study, the same results can be proved again wherein in view of the 'level of innovation', as a mediating variable, the illustrative power of the model studied here can be significantly improved. The results thus signpost a noteworthy role innovative behaviour as a mediator variable in the affiliation amongst ownership structure and board composition. Thereby, this supports the findings of prior studies like that of Schleifer and Vishny (1986).

Several empirical studies showed that the organisational environment and especially the governance structure of the firm has a vital impact on the innovation decision-making process (Aghion et al., 2009; Belloc, 2011). There is a noteworthy and positive affiliation between ownership concentration and manager's innovative behaviour, and the same is witnessed in this work. As a result, the majority of companies having a great percentage of inside directors, mainly involve innovation approaches and have come up with high performance.

Hence, for manufacturing firms, product innovations as per changing tastes and preferences as well as technology improvements are important and incremental changes are needed. The complexities of supply chain bring on the surface many kinds of risks and managing such risk successfully is needed.

\section{Implications}

This paper accepts innovation as the mediating variable to confirm the positive role of brought together of board and performance, and offers further hypothetical help for significant research in this field. The author suggests that leaders thinking about both worth creation and hazard control centre around figuring corporate administration systems, with specific consideration paid to yearly comprehensive meetings, cooperation, administrator and CEO split, governing body organisation, executive compensation and order, and straightforwardness of board structure and information of ownership. Significant research conclusion can likewise give reference and direction to manufacturing organisations to streamline board structure and improve administration framework practically speaking. Credit risk management is one of the pillars of corporate governance mechanisms. One should understand that governance activities of board can affect risk management significantly. Hence, regulators should emphasise on the risk management as the key responsibility of board.

As far as future course of research is concerned, a conceivable line of research would include a lot of investigations to setup contrasts by nation, contingent upon the kind of lawful framework to which they are subject. Different examinations have indicated that a nation's legitimate cause and its effect on speculator insurance and budgetary advancement impact an assortment of monetary viewpoints including money related markets, work and intensity, and subsequently portion of assets.

Panel data analysis or generalised methods of moment (GMM) techniques can also be used for further exploration of association. Though the paper has examined the mediation effect of innovative practices but it has not analysed the effect of board education, gender, size, experience on the performance as well as on the credit risk of the firms. 


\section{References}

Aggarwal, I. (2013) Cognitive Style Diversity in Teams, Dissertations, Paper No. 258.

Aghion, P., Bacchetta, P., Ranciere, R. and Rogof, K. (2009) Journal of Monetary Economics, Vol. 56, No. 4, pp.494-513.

Aghion, P., van Reenen, J.M. and Zingales, L. (2013) 'Innovation and institutional ownership', American Economic Review, Vol. 103, No. 1, pp.277-304.

Arora, A.P. (2012) 'Book Review: Steven Miles, space for consumption', Vision, Vol. 16, No. 3, pp.234-235, DOI: 10.1177/0972262912460957.

Asensio-López, D., Cabeza-García, L. and González-Álvarez, N. (2019) 'Corporate governance and innovation: a theoretical review', European Journal of Management and Business Economics, Vol. 28, No. 3, pp.266-284 [online] https://doi.org/10.1108/EJMBE-05-20180056.

Ayuso, S. and Argandona, A. (2007) Responsible Corporate Governance towards a Stakeholder "Board of Director's", WP No. 701, 'la Caixa' Chair of Corporate Social Responsibility and Corporate Governance.

Babic, V.M., Nikolic, J.D. and Eric, J.M. (2011) 'Rethinking board role performance: towards an integrative model', Economic Annals, Vol. 56, No. 190, UDC: 3.33, ISSN: 0013-3264.

Balsmeier, B., Buchwald, A. and Stiebale, J. (2014) 'Outside directors on the board and innovative firm performance', Research Policy, Vol. 43, No. 10, pp.1800-1815.

Balta, M.E., Woods, A. and Dickson, K. (2006) 'Strategic decision-making processes of the effect of board characteristics on company innovation', International Journal of Management, Vol. 30, No. 1, pp.311-328.

Barker III, V.L. and Mueller, G.C. (2002) 'CEO characteristics and firm R\&D spending', Management Science, Vol. 48, No. 6, pp.782-801.

Beekman, A.V., Steiner, S. and Wasserman, M.E. (2012) 'Where innovation does a world of good: entrepreneurial orientation and innovation outcomes in nonprofit organizations', Journal of Strategic Innovation and Sustainability, Vol. 8, No. 2, pp.22-36.

Belloc, F. (2011) 'International economic assistance and migration: the case of Sub-Saharan countries', International Migration, Vol. 53, No. 1, pp.187-201.

Blair, M.M. and Stout, L.A. (2001) 'Director accountability and the mediating role of the corporate board', Washington University Law Quarterly, Vol. 79, No. 2, pp.403-447.

Boone, A., Field, L., Karpoff, J. and Raheja, C. (2006) 'The determinants of board size and composition: an empirical analysis', Journal of Financial Economics, Vol. 85, pp.66-101, 10.1016/j.jfineco.2006.05.004.

Brunninge, O., Nordqvist, M. and Wiklund, J. (2007) 'Corporate governance and strategic change in SMEs: the effects of ownership, board composition and top management teams', Small Business Economics, Vol. 29, pp.295-308, DOI: 10.1007/s11187-006-9021-2.

Carpenter, M. and Westphal, J. (2001) 'The strategic context of external network ties: examining the impact of director appointments on board involvement in strategic decision making', The Academy of Management Journal, Vol. 44, No. 4, pp.639-660 [online] http://www.jstor.org/stable/3069408 (accessed 12 December 2020).

Cheung, Y-L., Connelly, J., Jiang, P. and Limpaphayom, P. (2011) 'Does corporate governance predict future performance? Evidence from Hong Kong', Financial Management. Vol. 40, pp.159-197, 10.2307/41237900.

Chieh, Y. (2013) 'Effect of capital structure on corporate performance', The Journal of Global Business Management, Vol. 9, No. 1, pp.92-105 [online] http://www.jgbm.org/page/10\% 20Yung-Chieh\%20Chien(revised).pdf.

Cho, M.H. (1998) 'Ownership structure, investment, and the corporate value: an empirical analysis', Journal of Financial Economics, Vol. 47, No. 1, pp.103-121. 
Chouaibi, J., Affes, H. and Boujelbene, Y. (2010) 'Characteristics of the board of directors and involvement in innovation activities: a cognitive perspective', International Journal of Managerial and Financial Accounting, Vol. 2, pp.240-255, DOI: 10.1504/IJMFA.2010. 034117.

Czarnitzki, D. and Kraft, K. (2009) 'Capital control, debt financing and innovative activity', Journal of Economic Behavior \& Organization, Vol. 71, No. 2, pp.372-383.

Daily, C.M. and Dalton, D.R. (2003) 'Women in the boardroom: a business imperative', Journal of Business Strategy, Vol. 24, pp.8-9.

Duzta, S., Icle, D. and Attilla, I. (2008) Corporate Governance: The Effects of Board Characteristics, Information Technology Maturity, and Transparency on Company Performance, $\mathrm{PhD}$ thesis, Graduate Institute of Social Sciences, Istanbul.

Ford-Eickhoff, K., Plowman, D.A. and McDaniel, R.R. (2011) 'Hospital boards and hospital strategy focus: the impact of board involvement in strategic decision making', Health Care Management Review, Vol. 36, No. 2, pp.145-54, DOI: 10.1097/HMR.0b013e3182099f6e.

Galasso, A. and Simcoe, T.S. (2011) 'CEO overconfidence and innovation', Management Science, Vol. 57, No. 8, pp.1469-1484.

Ghazi, Z. and Rim, Z-H. (2015) 'Directors' board, R\&D investment and firm's performance: evidence from France', Corporate Board: Role, Duties and Composition, Vol. 11, pp.107-122, DOI: $10.22495 /$ cbv11i1c1art3.

Gil, M. (2005) 'Governing boards' performance and organizational effectiveness', Conference: Boards and Beyond, University of Kansas City, Missouri.

Green, P.J. (1995) 'Reversible jump Markov chain Monte Carlo computation and Bayesian model determination', Biometrika, December, Vol. 82, No. 4, pp.711-732 [online] http://links.jstor.org/sici?sici=0006-3444\%28199512\%2982\%3A4\%3C711\%3ARJMCMC\% 3E2.0.CO\%3B2-F.

Gugong, B., Arugu, L. and Dandago, P. (2014) 'The impact of ownership structure on the financial performance of listed insurance firms in Nigeria', International Journal of Academic Research in Accounting, Finance and Management Sciences, 2225-8329, Vol. 4, pp.409-416, DOI: $10.6007 / \mathrm{IJARAFMS} / \mathrm{v} 4-\mathrm{i} 1 / 698$.

Haldar, A. (2017) 'Assessment of the role of independent director and its effectiveness for the growth and development of shareholders' value of the firm' [online] https://www.independentdirectorsdatabank.in/pdf/partners/NFCG/SPJAINassessment $\% 20$ of $\% 20$ the $\% 20$ role $\% 20$ of $\% 20$ independent.pdf (accessed 12 February 2020).

Haldar, A. and Rao, S.N. (2011) 'Empirical study on ownership structure and firm performance', Indian Journal of Corporate Governance, Vol. 4, No. 2, pp.27-34, DOI: 10.1177/ 0974686220110203.

He, J. and Mahoney, J.T. (2006) Firm Capability, Corporate Governance, and Firm Competitive Behavior: A Multi-theoretic Framework, Working Papers 06-0103, College of Business, The University of Illinois at Urbana-Champaign.

Hirshleifer, D. (1993) 'Managerial reputation and corporate investment decisions', Financial Management, Vol. 22, No. 2, pp.145-160.

Kang, E. and Zardkoohi, A. (2005) 'Board leadership structure and firm performance', Corporate Governance: An International Review, Vol. 13, No. 6, pp.785-799, https://doi.org/10.1111/ j.1467-8683.2005.00470.x.

Koufopoulos, D.N. and Gkliatis, I.P. (2018) 'An exploration of the effect of organisational demography on board size and leadership structure: evidence from the Greek manufacturing sector', Corporate Board: Role, Duties and Composition, Vol. 14, No. 3, SSRN: https://ssrn.com/abstract=3278686.

Lipton, M., Niles, S.V. and Miller, M.L. (2018) Risk Management and the Board of Directors [online] https://corpgov.law.harvard.edu/2018/03/20/risk-management-and-the-board-ofdirectors-5// (accessed 15 May 2020).

Manso, G. (2011) 'Motivating innovation', Journal of Finance, Vol. 66, No. 5, pp.1823-1860. 
Mention, A-L. (2012) 'Intellectual capital, innovation and performance', Business and Economic Research, Vol. 2, No. 1, pp.1-37, ISSN: 2162-4860.

Miller, T. and Trian, M.D.C. (2009) 'Demographic diversity in the boardroom: mediators of the board diversity-firm performance affiliation', Journal of Management Studies, Vol. 46, No. 5, pp.755-786, https://doi.org/10.1111/j.1467-6486.2009.00839.x.

Ortega-Argilés, R., Moreno, R. and Caralt, J.S. (2005) 'Ownership structure and innovation: is there a real link?', The Annals of Regional Science, Vol. 39, No. 4, pp.637-662.

Pisano, G.P. (2015) You Need an Innovation Strategy, June [online] https://hbr.org/2015/06/youneed-an-innovation-strategy (accessed 13 April 2020).

Rathnayake, D.N. and Sun, G. (2017) 'Corporate ownership, governance and performance: evidence from Asian countries', Research Journal of Finance and Accounting, Vol. 8, No. 15, pp.28-36, SSRN: https://ssrn.com/abstract=3134585.

Robeson, D. and O'Connor, G.C. (2013) 'Boards of directors, innovation, and performance: an exploration at multiple level', J. Prod. Innov. Manag., Vol. 30, No. 4, Product Development \& Management Association, DOI: 10.1111/jpim.12018.

Shadab, H.B. (2008) 'Innovation and corporate', U. PA. Journal of Business and Employment Law, Vol. 10, No. 4, pp.955-1008.

Shapiro, D., Tang, Y., Wang, M. and Zhang, W. (2015) 'The effects of corporate governance on innovation in Chinese firms', Journal of Chinese Economic and Business Studies, Vol. 13, No. 4, pp.311-335.

Shleifer, A. and Vishny, R.W. (1986) 'Large shareholders and corporate control', Journal of Political Economy, Vol. 94, No. 3, pp.461-488.

Staubo, S. (2014) Regulation and Corporate Board Composition Investigated the Effects of Regulations on Board Composition, Series of dissertations 1/2014, ISBN: 978-82-8247-084-1, ISSN: 1502-2009.

Tacheva, S. and Huse, M. (2006) 'Women directors and board task performance: mediating and moderating effect of board working style', Draft of paper to be presented at the EURAM Meeting 2006.

Talke, K., Salomo, S. and Rost, K. (2010) 'How top management team diversity affects innovativeness and performance via the strategic choice to focus on innovation fields', Research Policy, Vol. 39, No. 7, pp.907-918.

Ughetto, E. (2010) 'Assessing the contribution to innovation of private equity investors: a study on European buyouts', Research Policy, Vol. 39, No. 1, pp.126-140.

Ukaegbu, B., Oino, I. and Dada, F.B. (2014) 'Impact of ownership structure on capital structure and firm's performance', Research Journal of Finance and Accounting, Vol. 5, No. 15, ISSN: 2222-1697 (paper), ISSN: 2222-2847 (online). 